\title{
Roman Catholic
}

National Cancer Institute

\section{Source}

National Cancer Institute. Roman Catholic. NCI Thesaurus. Code C103286.

A religious group that has beliefs derived from the first practicing Christians and is led by the pope, or bishop of Rome. 